\title{
Statyba
}

\section{NUMERICAL INVESTIGATIONS OF HEAT TRANSFER IN A TROMBE'S WALL}

\author{
Dr Habil Eng. H. Koczyk \& A. Górka MSc (Eng)
}

To cite this article: Dr Habil Eng. H. Koczyk \& A. Górka MSc (Eng) (1996) NUMERICAL INVESTIGATIONS OF HEAT TRANSFER IN A TROMBE'S WALL, Statyba, 2:6, 73-79, DOI: 10.1080/13921525.1996.10531647

To link to this article: https://doi.org/10.1080/13921525.1996.10531647

曲 Published online: 26 Jul 2012.

Submit your article to this journal $\pi$

LII Article views: 131

4 Citing articles: 1 View citing articles 준 


\section{NUMERICAL INVESTIGATIONS OF HEAT TRANSFER IN A TROMBE'S WALL}

\section{Koczyk, ^. Górka}

\section{Introduction}

Many solutions have been proposed to save energy for heating in passive solar systems such as direct gains, attached sunspace, Trombe's wall $[1,2,3,4]$ and so on.

The paper presents numerical model of a building with passive solar system, in particular, direct or indirect. Exemplary results obtained by means of this model in climatic conditions of Poznan are presented.

\section{Problem formulation}

The problem under consideration is heat transfer in a building with passive solar system in the form of Trombc's wall with gravitational air flow and direct gains.

The mathematical model of a building constitutes the systems of partial differential equations which describe heat conduction in material layers, the equations of heat balance for the rooms of building and equations describing a flow and heat transfer in Trombe's wall air-gap.

System of model equations is completed by boundary and initial conditions systems.

The following main assumptions have been made:

- walls forming the enclosure are discussed as multilayered plane walls,

- air temperature is assumed to be equal in a room space,

- heat conduction in material layers is considered as being one-dimensional, disregarding corners, thermal bridges and window framings,

- heat transfer on internal surfaces of the walls takes place with constant heat convection coefficients,

- heat convection coeflicients on external surfaces of the walls are wind speed functions,
- transmittance coefficient for glazing depends on sun's position,

- air flow inside Trombe's wall air-gap is considered as gravitational resulting from density difference,

- climatic factors: external air temperature and solar radiation in the form of average hourly courses for two kinds of day: solar and cloudy, for each month are given.

The aim of this paper is therefore to present a numerical model based on finite difference method $[5,6,7,8,9]$, which is able to calculate the thermal behaviour of a building with indirect and direct passive solar systems, in particular ventilation efficiency of Trombe's wall with gravitational air flow inside its airgap.

The presented method can be used also for analysing of thermal balance components for buildings equipped with passive solar system and conventional heating system.

\section{Accepted numerical model of a building with passive solar system}

To solve a model of a building with passive solar system ( PSS ) implicit finite difference method has been used.

Schematic model of a fragment of building enclosure with PSS based on quantization method is shown in Fig. 1.

The building is considered as a set of rooms characterized by different appropriation and maintenance, connected by walls of different construction.

Construction of a numerical model of building includes calculation of distribution of temperatures in all walls forming the enclosure, composition of system of energy balance equations for nodes representative of rooms and its solution. 


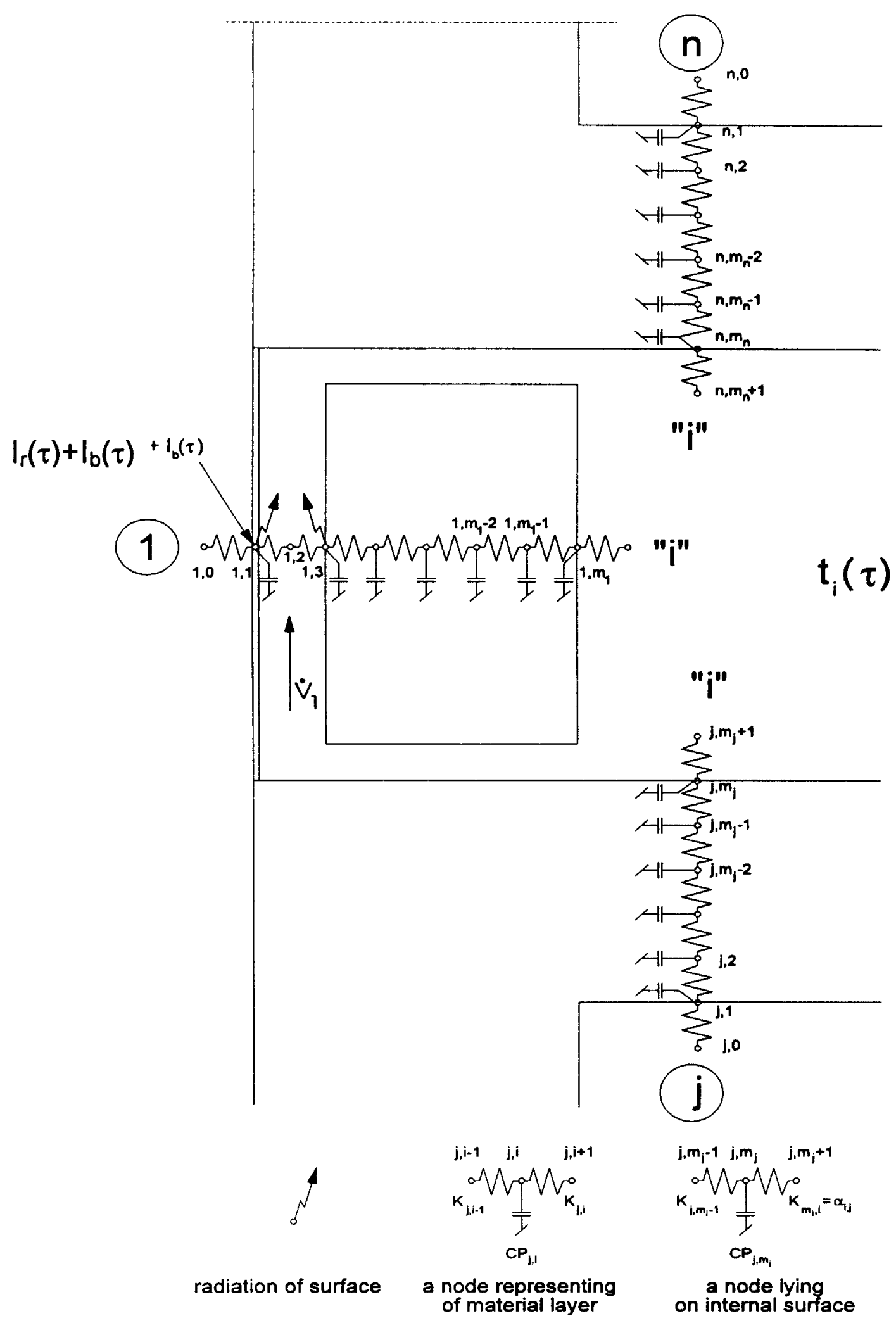

Fig. 1. Schematic diagram of a building enclosure with passive solar system based on quantization method. 
Numerical model of individual room composed of " $n$ " walls, in which a structure of each wall is represented by " $m_{j}$ " nodes, constitutes a system of $\mathrm{cn}$ ergy balance equations.

The number of equations for individual room is equal:

$$
N=\sum_{j=1}^{j=n} m_{j}+1
$$

Temperatures in all nodes of walls (except nodes "j,0", in which temperature results from boundary conditions) are unknowns in a system of equations.

With reference to Fig. 1 energy balance equations for characteristic nodes are as follows:

- for a node representative of material layer

$K_{j, i-1}\left(\mathrm{X}_{j, i-1}-X_{j, i}\right)+K_{j, i}\left(\mathrm{X}_{j, i+1}-\mathrm{X}_{j, i}\right)=$

$=\frac{C P}{D t}\left(\mathrm{X}_{j, i}-T_{j, i}\right)$

- for a node representative of a glazing of Trombe's wall

$$
\begin{aligned}
& \alpha_{e}\left(X_{e}-X_{1,1}\right)+\alpha_{C O N 1,1}\left(X_{1,2}-X_{1,1}\right)+\alpha_{R A D 1.3} \\
& \left(X_{1.3}-X_{1.1}\right)+a_{1}\left(I_{r}+I_{b}\right)=\frac{C P_{1,1}}{\Delta \tau}\left(X_{1.1}-T_{1,1}\right) \\
& \text { - for a node representative of air-gap in }
\end{aligned}
$$

Trombc's wall

$$
\begin{aligned}
& \alpha_{\operatorname{CON} 1,2}\left(X_{1,1}-X_{1,2}\right)+\alpha_{\operatorname{CON} 2,3}\left(X_{1,3}-X_{1,2}\right)+ \\
& +\dot{V}_{1} \rho c_{p}\left(X_{i}-X_{1,2}\right)=\frac{C P_{1,2}}{\Delta \tau}\left(X_{1,2}-T_{1,2}\right)
\end{aligned}
$$

- for a node lying on absorptive surface of accumulating material layer in Trombe's wall

$$
\begin{aligned}
& \alpha_{C O N 2,3}\left(X_{1,2}-X_{1,3}\right)+K_{3,4}\left(X_{1,4}-X_{1,3}\right)+ \\
& +\alpha_{R A D 3,1}\left(X_{1,1}-X_{1,3}\right)+a_{3}\left(\tau_{\alpha}\right)\left(I_{r}+I_{b}\right)= \\
& =\frac{C P_{1,3}}{\Delta \tau}\left(X_{3,3}-T_{1,3}\right)
\end{aligned}
$$

- for a node lying on internal surface of walls that form enclosure of a room

$$
\begin{aligned}
& K_{j, m_{j}-1}\left(X_{j, m_{j}-1}-X_{j, m_{j}}\right)+K_{j, m_{j}}\left(X_{i}-X_{j, m_{j}}\right)= \\
& =\frac{C P_{j, m_{j}}}{\Delta \tau}\left(X_{j, m_{j}}-T_{j, m_{j}}\right)
\end{aligned}
$$

- for a node representative of an air in the room

$$
\begin{aligned}
& \sum_{j=1}^{j=n} K_{j, m_{j}}\left(X_{j, m_{j}-1}-X_{j, m_{j}}\right) A_{i, j}+\dot{Q}_{H}(\tau)+ \\
& +n(\tau) c_{p} \rho V\left(X_{e}-X_{i}\right)=\frac{c_{p} \rho V}{\Delta \tau}\left(X_{i}-T_{i}\right)
\end{aligned}
$$

List of the most important symbols used in the equations:

a - absorption coefficient,

A - internal area $\left[\mathrm{m}^{2}\right]$,

c - specific heat capacity of air $\left[\mathrm{Jkg}^{-1} \mathrm{~K}^{-1}\right]$,

$\mathrm{CP}$ - thermal capacity $\left[\mathrm{Jm}^{-3} \mathrm{~K}^{-1}\right]$,

$\mathrm{J}$ - solar radiation [ $\mathrm{Wm}^{-2}$,

$\mathrm{K}$ - thermal conductivity $\left[\mathrm{Wm}^{-2} \mathrm{~K}^{-1}\right]$,

n - ventilation rate [s],

$\dot{\mathrm{Q}}$ - heat flow [W],

$\mathrm{T}$ - actual temperature in a node (at the beginning of time interval) $\left[{ }^{\circ} \mathrm{C}\right]$,

$\mathrm{X}$ - forecast temperature in a node (at the end of time interval) $\left[{ }^{\circ} \mathrm{C}\right]$,

$\mathrm{V}$ - ventilated volume $\left[\mathrm{m}^{3}\right]$,

$\dot{\mathrm{V}}_{1}$ - volumetric air change rate in Trombe's wall $\left[\mathrm{m}^{3} \mathrm{~s}^{-1}\right]$

$\rho$ - density $\left[\mathrm{kgm}^{-3}\right]$,

$\alpha$ - surface film conductance $\left[\mathrm{Wm}^{-2} \mathrm{~K}^{-1}\right]$,

$\Delta \tau$ - interval of the time [s],

$\left(\tau_{\alpha}\right)$ - transmittance of solar radiation.

List of subscripts :

b - direct,

CON - convection,

e - external,

$\mathrm{H}$ - heating,

i - number of a node, internal,

j - number of a wall (1-Trombe's wall),

$\mathrm{m}$ - number of material layers,

$r$ - diffuse,

$\mathrm{RAD}$ - radiation,

s - solar,

w - window.

The system of equations of energy balances ought to be solved for each wall in every step of time. The system of equations which binds all the equations systems for walls forming the enclosure of individual room is the system of equations of thermal balance for nodes representative of an air in single rooms (7). 
Convective heat transfer coefficients for surfaces forming an air-gap are given by Barra [1]

$$
N u=4.35 G r^{0.22}
$$

where Nu - Nusselt number,

Gr - Grashoff number.

For convection on external surfaces the following expression was used:

$$
\alpha_{\mathrm{e}}=5.7+3.8 \mathrm{w}
$$

with $w$ - wind velocity $\left[\mathrm{ms}^{-1}\right]$.

Standard gencralized transmittance of solar radiation through glazing is given in the form of formula:

$$
\tau_{\alpha}=\alpha_{1} \alpha_{2} \alpha_{3}\left(\tau_{\alpha}\right)_{s}
$$

where $\alpha_{1}, \alpha_{2}, \alpha_{3}$ are correction coefficient and

$\left(\tau_{\alpha}\right)_{s}$ depends on sun's position.

Volumetric air change rate in Trombe's wall depends on the total pressure drop throughout the airgap and the gravitational pressure resulting from density difference, according to the expression :

$$
\mathrm{h} \Delta \mathrm{\rho g}=\Delta \mathrm{p}_{\mathrm{c}}
$$

where :

$h$ - height of an air-gap $[\mathrm{m}]$,

$\Delta \rho$ - density difference $\left[\mathrm{kgm}^{-3}\right]$,

$g$ - acceleration of gravity $\left[\mathrm{ms}^{-1}\right]$,

$4 p_{c}$ - total pressure drop throughout the air-gap [Pa].

Total pressure drop throughout the air-gap is composed of pressure losses caused by frictional resistance and pressure losses caused by local resistances.

Coefficient of internal friction is calculated from equations given by Hagen-Pouisseuille (for laminar flow) and by Colebrook-White (for turbulent flow).

The above procedure gives temperature distributions in all elements forming the building in every time step of simulation period.

\section{Model of external climate}

The model of external climate for Poznan was claborated in the form of Average Reference Year [10] on the ground of meteorological data from ten years period.
Basic data relating to external temperature for Avcrage Reference Year for Poznan are shown in Fig. 2.

Accepted courses of direct radiation falling on surface perpendicular to sun beam are presented in Fig. 3 and courses of diffuse radiation are presented in Fig. 4. Data of ARY were stored in a disk file.

\section{Results of modelling}

The room with south orientated Trombe's wall double glazing was taken as a model for calculation. The volume of the room is $40 \mathrm{~m}^{3}$.

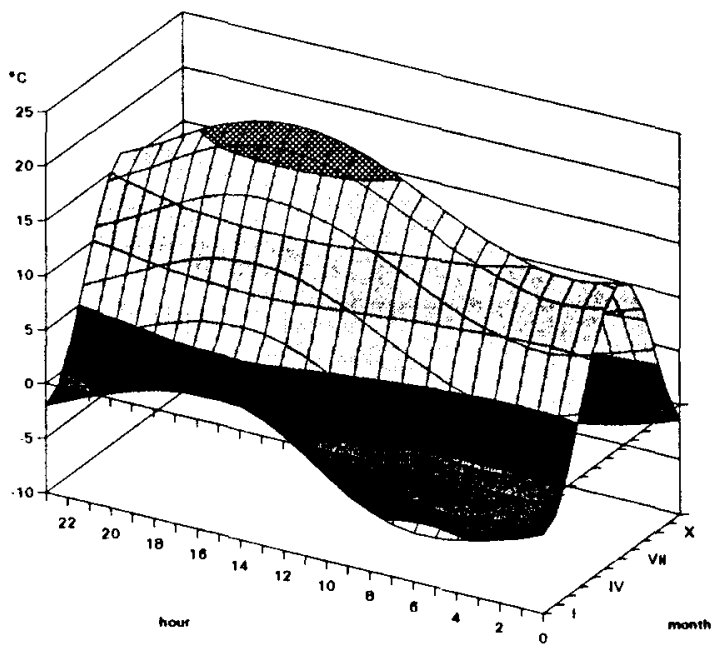

Fig. 2. Accepted courses of external temperature in ARY of Poznan.

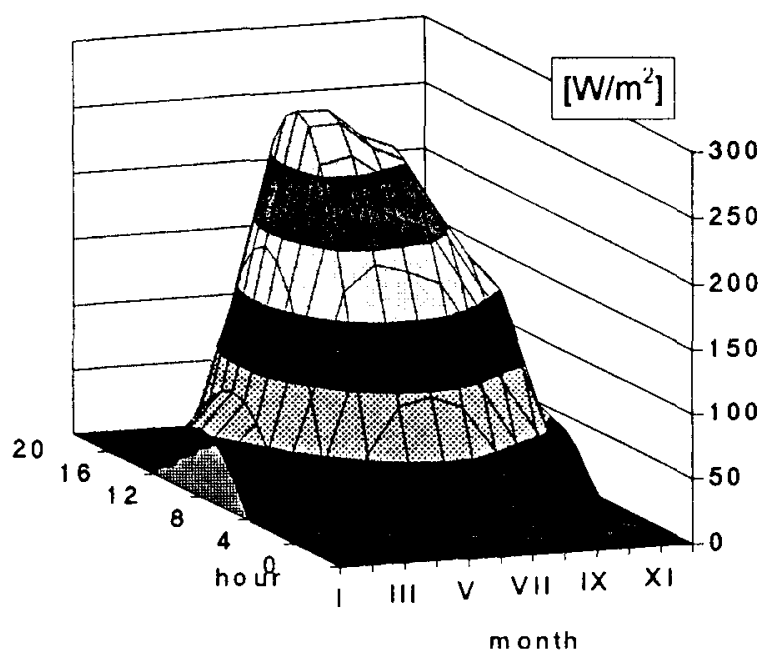

Fig. 3. Accepted courses of direct radiation for Poznan. 


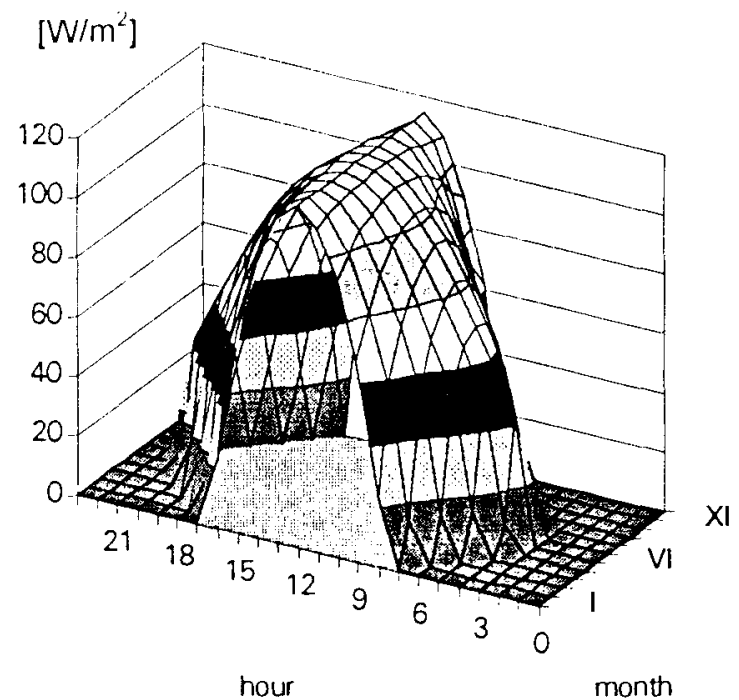

Fig. 4. Accepted courses of diffuse radiation for Poznan.

Construction of Trombe's wall is as follows: $\sin$ gle or double glazing, an air-gap $0.15 \mathrm{~m}$ thickness, brick work accumulating layer $0.25 \mathrm{~m}$ thickness.

The second external wall is east orientated and is composed of $0.24 \mathrm{~m}$ cellular concrete, $0.04 \mathrm{~m}$ foamed polystyrene, $0.04 \mathrm{~m}$ air-gap and $0.12 \mathrm{~m}$ brickwork ( overall heat transfer coefficient $k=0.44 \mathrm{~W} / \mathrm{m}^{-2} \mathrm{~K}^{-1}$ ). This wall has double-glazed window.

The floor and the ceiling are situated between heated rooms. They have overall heat transfer coefficient $\mathrm{k}=1.37 \mathrm{~W} / \mathrm{m}^{-2} \mathrm{~K}^{-1}$ ).

The air change rate $\mathrm{n}=0.5 \mathrm{~h}^{-1}$. The target of calculations was analysis of variability of volumetric air change rate through the air-gap of Trombe's wall in Average Reference Year of Poznan as well as analysis of variability of thermal balance components in this period. Calculations were done for Average Reference Year for Poznan for sunny and cloudy days with defined occurence frequency. The following assumption has been made - the used room is equipped with direct and indirect passive solar system and conventional heater with thermoregulator which secures $20^{\circ} \mathrm{C}$ - given internal air temperature.

Two kinds of air flow regulation through the airgap of Trombe's wall are considered :

- case A - outllow of the air to room comes after the temperature of incoming air raises above the required temperature $t_{\text {in }}>20^{\circ} \mathrm{C}$
- case B - outflow of the air to room comes after the temperature of incoming air contains in specified interval $20^{\circ} \mathrm{C}<\mathrm{t}_{\text {in }}<24^{\circ} \mathrm{C}$

Exemplary results in the form of variability of air change rate and thermal balance for the room with double glazing Trombe's wall are shown in the Fig. 5. Courses of variability of volumetric air change through the air-gap of Trombe's wall $\dot{\mathrm{V}}_{\text {mean }}$ and $\dot{\mathrm{V}}_{\max }$ in Average Reference Year of Poznan are presented in Fig. 5. Courses of ventilation heat gains issuing to application of Trombe's wall $\dot{\mathrm{Q}}_{\mathrm{v} \text { mean }}$ and $\dot{\mathrm{Q}}_{\mathrm{v} \max }$ are shown in Fig. 6. The course of maximal internal temperature $t$ imax in the room with Trombe's wall without shading devices are shown in Fig. 7. Courses of characteristic heat fluxes $\dot{Q}_{\text {overall }}$ for Trombe's wall and required heating output for the room $\dot{Q}_{\text {Hmean }}$ and $\dot{Q}_{\mathrm{H} \max }$ are presented in Fig. 8. Infiltration losses $\dot{Q}_{\text {inf }}$ and transmission losses through east orientated external wall $\dot{\mathrm{Q}}_{\text {Ewall }}$ and window $\dot{\mathrm{Q}}_{\text {wind }}$ are shown in Fig. 9.
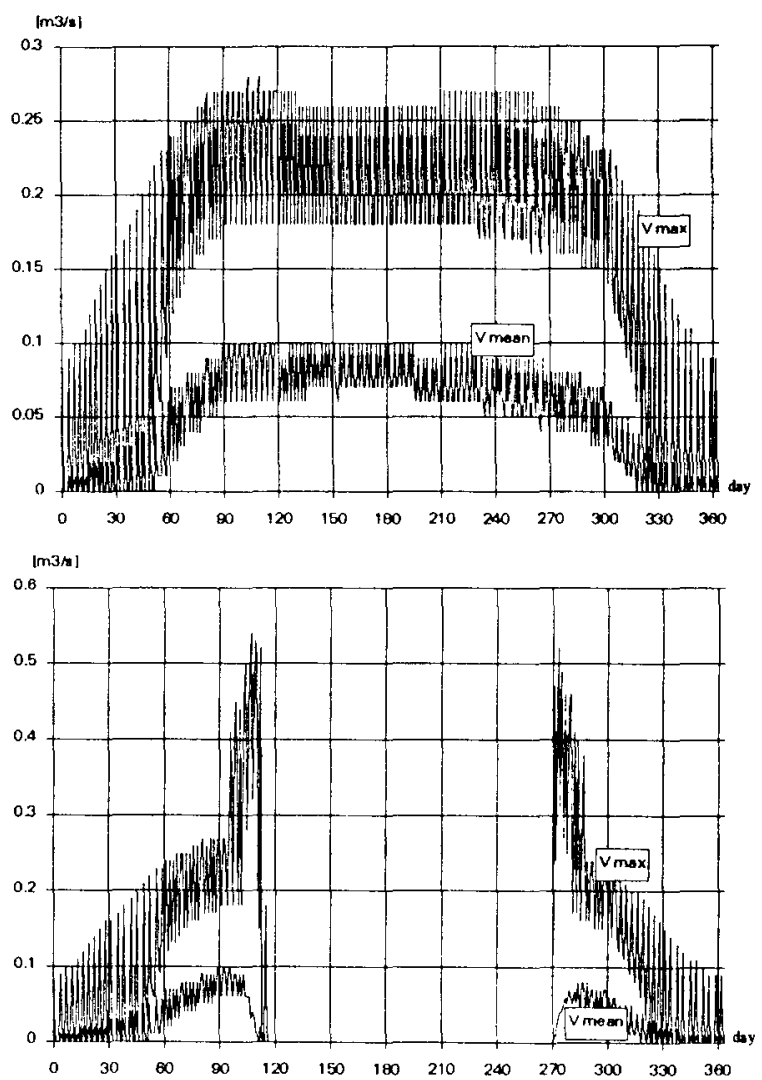

Fig. 5. Variability of volumetric air change rate through the air-gap of Trombe's wall in ARY of Poznan - case A and case $\mathrm{B}$. 

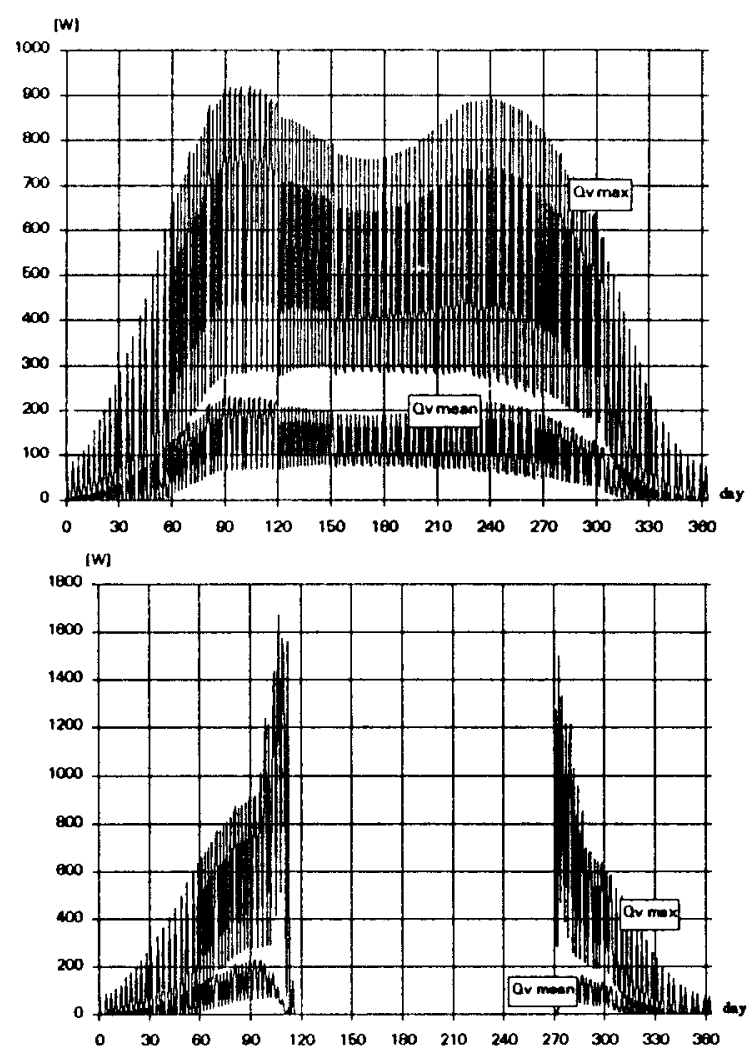

Fig. 6. Variability of ventilation heat gains for Trombe's wall in ARY of Poznan - case A and case B.
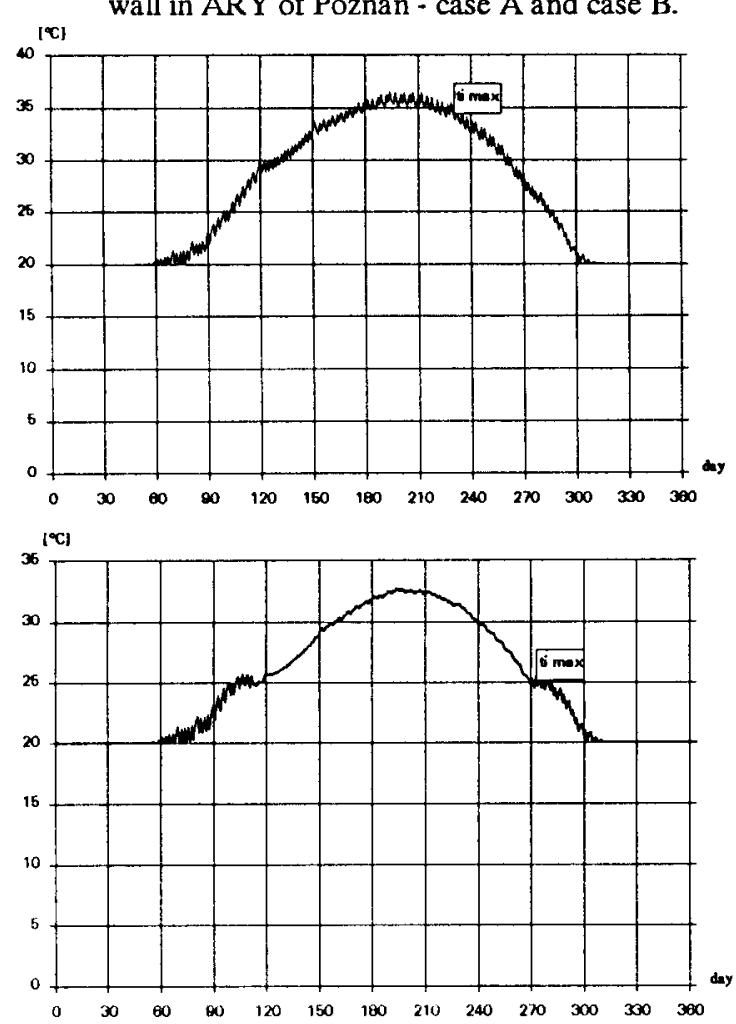

Fig. 7. Maximal internal air temperatures in the room with Trombe's wall in ARY of Poznan - case A and case B.
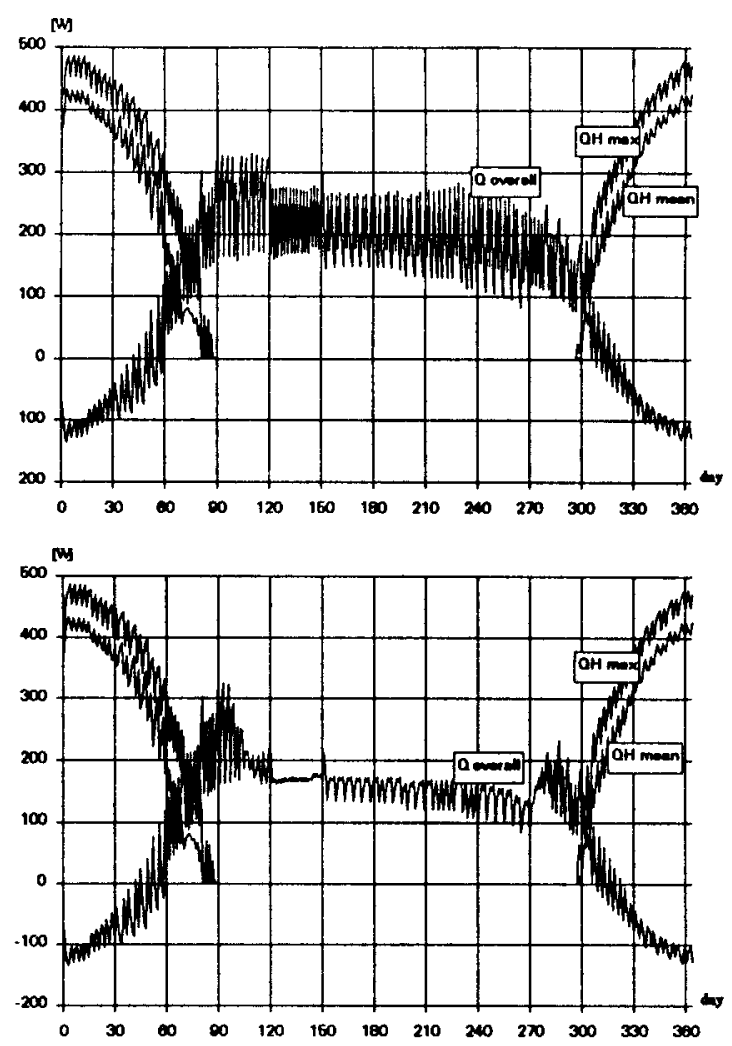

Fig. 8. Variability of heat flux for Trombe's wall and required heating output for the room with indirect passive solar system in ARY of Poznan- case A and case B. [w]

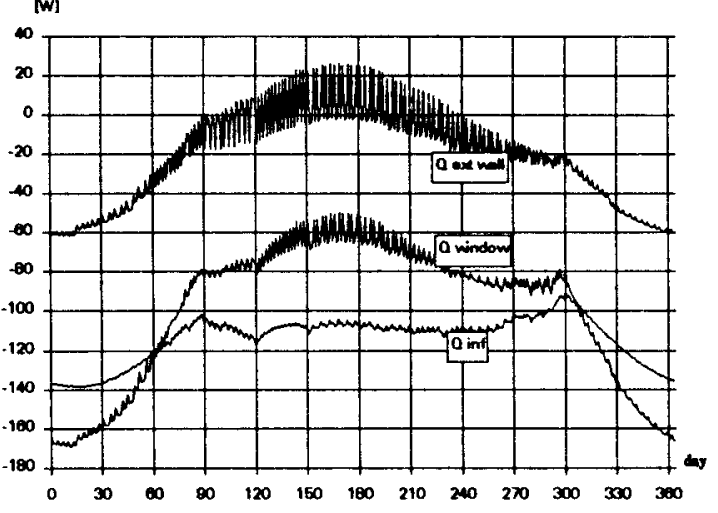
[m]

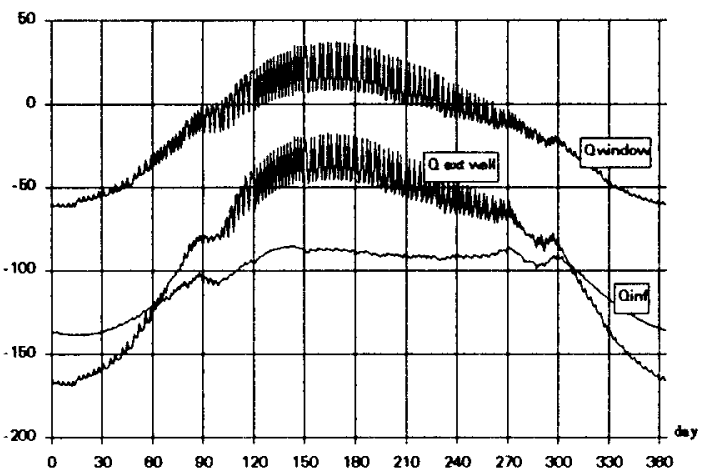

Fig. 9. Variability of transmission and ventilation losses for the room with Trombe's wall in ARY of Poznan - case A and case $B$. 


\section{Conclusions}

Trombe's wall is the source of room overheating in summer months, independently of kind of air flow regulation method. It has to be equipped with shading devices.

The presented algorithms and elaborated computer program can be applied to other investigations of thermal behaviour of heated buildings with passive solar systems, among other things, ventilation efficiency of Trombe's wall with gravitational air flow inside its air-gap.

\section{References}

1. G. Cammarata, L. Marletta, F. Patane, F. Patania. Passive Cooling of Building in Warm Climates by Means of the Barra-Constantani System. Thermal Dynamics and Performance Evaluations // The First International PLEA Conference "Passive and Low Energy Alternatives I", Bermuda 1982, p.10.1-10.7.

2. E. Ilahne, K. Spindler. Passive Solarenergienutzung mit ciner Trombewand // Prace Nauk. Inst. Inz.Chem. i Urz. Ciepln. Pol. Wrocl. 1984, 44, p. 204-215.

3. R.W. Jones, R.D. Mc Farland. The Sunspace Primer. A Guide for Passive Solar Heating // Publ. by Van Nostrand Reinhold Comp. Inc., New York, 1984.

4. R.M. Lebens. Passive Solar Heating Design // Appl. Sc. Publ. Lid, London, 1984.

5. W.N. Bogoslowski. Fizyka budowli. Warszawa: Arkady, 1975.

6. H. Koczyk. Stosowanie metod różnicowych w modelowaniu wymiany ciepla $w$ pomieszczeniu $z$ niestacjonarnym źródlem ciepła // Mat. XI Zj. Termodyn. Swinoujscie, 1981, p. 263-266.

7. H. Koczyk. Modelowanie numeryczne wymiany ciepła wewnątrz pomieszczenia $w$ analizie ogrzewań niestacjonarnych // Prace Nauk. Inst. Inz. Chem. i Urz. Ciepln. Pol. Wrocl., 1987, 50, p. 229-235.

8. R.W.R. Muncey. Heat Transfer Calculations for Buildings // London: Appl. Sc. Publ. Ltd, 1980.

9. U.Dale Rosenberg. Mcthods for the Numerical Solution of Partial Differential Equations. New York: A.E.P.C.Inc., 1969.

10. B. Antonicwicz, H. Koczyk. Modele klimatu zewnźtrznego m. Poznania // Zesz. Nauk. PP Pol. Pozn. 32, 1990 , p. $285-295$.

Itcikta 19960410

\section{SKAITINIS ŠILUMOS PERDAVIMO TROMBE'S SIENOJE TYRIMAS}

\section{H.Koczyk, Górka}

San trauk a

Straipsnyje nagrinèjama, kaip taikyti baigtiniy skirtumy metodą šlumos perdavimo modeliui sukurti pastatams, kurie naudojasi pasyviaja saulès sistema, ypac tiesiogine ar netiesiogine. Pateiktieji algoritmai bei skaixiavimo programa gali būti taikomi Siluminès pusiausvyros elementams tirti nurodyto tipo pastatuose, be to, nustatyti ir vèdinimo efektyvumui Trombe's sienoje, pasižyminčioje savitakiu oro srautu vidinèmis tuštumomis.

Straipsnyje pateikiamas Poznanès lauko klimato modelis, pagristas vidutiniais metu duomenimis. Pateikti ir Poznanès klimato sąlygoms büdingi pavyzdiniai rezultatai, susiję su Siluminès pusiausvyros elementais patalpoje su pasyviaja saulès sistema. Ivertintas ir oro kaitos greitis Trombe's sienoje su savitakiu oro srautu, susidaranciu dèl tankio skirtumy.

Halina KOCZYK. Dr Habil Eng. Poznan University of Technology, 3A Piotrowo Str. 60-965 Poznan, Poland

Professor at Dept of Heating, Air Conditioning and Air Protection. Institute of Environmental Engineering. Vice-dean of Faculty of Civil and Environmental Engineering and Architecture. M Sc (Eng) diploma in 1970, $\mathrm{Ph} \mathrm{D}$ in 1978, habilitation in 1990 at Poznan UT. Research interests: heat transfer in buildings, energy savings.

Andrzej GÓRKA. M Sc (Eng) Poznan University of Technology, 3A Piotrowo Str. 60-965 Poznan, Poland

Assistant at Dept of Heating, Air Conditioning and Air Protection. Institute of Environmental Engineering. M Sc (Eng) diploma in 1993 at Poznan UT. Research interests: numerical modelling, passive solar systems. 